\title{
Idiomatic Expressions of the Sewing Frame in English and their Persian Counterparts: Nida's Dynamic Equivalence Theory in Focus
}

\author{
Banafsheh Ghafel (Corresponding author) \\ Graduate Candidate of TEFL \\ Department of English, Islamic Azad University- Najafabad Branch, Isfahan, Iran \\ Tel: 98-91-3235-0547 E-mail: banafshehghafel@yahoo.ca \\ Abbass Eslami Rasekh \\ Assistant Professor of Applied Linguistics \\ Department of English, Faculty of Foreign Languages, University of Isfahan, Iran \\ Tel: 98-91-3110-3984 E-mail:abbasseslamirasekh@yahoo.com
}

\author{
Abdolreza Pazhakh \\ Assistant Professor of Teaching \\ Islamic Azad University-Dezful \\ Branch, Khuzestan, Iran
}

Received: December 3, 2010 Accepted: February 28, 2011 doi:10.5539/ies.v4n2p160

\begin{abstract}
Translation is an act of communication across dissimilar cultures. In as such, cultural expressions or idioms are a particularly salient translation challenge, especially when translating between two distinct languages spoken by two different nations. Idioms convey rich cultural connotations, and so require consideration of both cultural and linguistic dissimilarities when providing for translation.

This article describes findings for idiomatic expressions within the sewing frame and their Persian equivalences in the framework of Nida's Dynamic Equivalence theory to answer such questions of translation. Specifically, to what extent Persian idiomatic expressions overlap this frame in English connotatively is explored on one hand; as compared to their differences in using source domains, on the other.

To do so, twenty seven sewing frame idiomatic expressions in English were collected from the work of Uberman (2008), website of http://www.UsingEnglish.com/idiom.asp ， http://goenglish.com/idiom.asp and http://www.idiomeanings.com. Next their Persian equivalences were searched for and directly compared. The results show that the overlapping of idioms in this frame is mostly connotatively oriented and that there are some English expressions that have zero idiomatic equivalence in Persian.
\end{abstract}

Keywords: English Idiomatic expression, Persian idiomatic expression, Sewing frame, Nida's Dynamic Equivalence theory

\section{Introduction}

According to Webster Dictionary, idiomatic expressions include idioms, proverbs, slang, famous quotations and other fixed expressions. Idiom means a speech form or an expression of a given language that is peculiar to it grammatically or can't be understood from the individual meanings of its elements (Macmillan: 710:2003), e.g. "gets the needles" that means 'become angry'. Idiomatic expressions (e.g., idioms, proverbs) are widely recognized as the mirror of national characteristics embodied in a language. They are products of cultures and an important part of the language and culture of the society (Ji-Xin, 2009). Idioms usually carry more impact than non-idiomatic expressions because of their close identification with a particular language and culture (Nida, 2001:28). This colorful aspect of language is used to communicate one's thoughts and feelings, to give life and richness to language by taking the existing words, combining them in a new sense and creating new meanings, just like a work of art (Lennon, 1998). 
In keeping the discussion going, idioms are usually culture-loaded expressions and in translation of them, much attention should be paid to the dissimilarities of cultures as well as language. Tong (2007) stated that in cross-cultural interactions, each language may choose different sources to present the same idea or these two languages may choose the same source to create idioms with dissimilar implications. The way in which the source of idioms would be transferred is very important to translation and cross-cultural interactions.

Translation studies stem from comparative literature and contrastive analysis. They involve the transfer of a message between two different language systems and cultures. English and Persian are genetically unrelated languages with different cultural identities. The main culture differences between English and Persian idioms lie not only in the language expressions but carved and endow with rich cultural characteristics of the nation and the society.

In translation of SL into TL, finding TL translation equivalent needs to be faithful to the original text. Catford once said "the central problem of translation practice is finding TL translation equivalences."(Catford, 1965:21).This equivalence is not complete or absolute, but dynamic and functional - just the closest natural equivalence of the original. For instance, when unrecoverable misfortune is the target, English speakers use the idiom 'to cry over spilled milk' while Persian speakers use ' 'آب ريخته شده را نميتوان جمع كرد 'b ri:xtəh shu:dəh r^n nəmi:tæv^n jæm? Kærd/ which means 'spilled water is not to be gathered up'.

Considering Nida's Dynamic Equivalence theory, twenty-seven English sewing frame idioms with their Persian equivalences have been included. In comparing the cultural differences and similarities of these two languages, first we search for English sewing frame idioms followed by the Persian idioms with similar connotations. Ultimately, only those English idioms that have Persian equivalences remain for discussion. The ones that lack Persian correspondents are considered as zero equivalence.

\section{Nida's Dynamic Equivalence}

The definition of dynamic equivalence is firstly given by Eugene A. Nida in his book Toward a Science of the Translation (Nida, E.A., 1964:161). Nida is an American translation theorist as well as linguist. His major contributions to modern translation studies are "the scientific study of translation " and " the principle of equivalence".

Nida argued that there are two different types of equivalence, namely formal equivalence and dynamic equivalence. Formal equivalence deals with the message itself, in both form and content whereas dynamic equivalence translation is based on the principle of equivalent effect. The translator is not concerned with the source language message, but rather with the dynamic relationship. Namely, the relationship between receptor and the message should be substantially the same as that which existed between the original receptors and the message. While formal equivalence focuses on source language text, dynamic equivalence centers on the communicative effect on target language receivers.

Dynamic equivalence fits the receptor language and culture in order to make translated messages intelligible and natural to target language receptors. For instance, if we translate a phrase like 'Carrying coal to Newcastle' literally into Persian, it will produce a nonsensical meaning for the Persian receptor. Idiomatic expressions make no sense when translated literally from one language to another. In such cases the equivalence counterpart يره به كرمان بردن / zi:rəh bəh kərm^n bu:rdæn/ (Kerman is a city in south part of Iran) can be used to make it understandable to the receptor. For this idiom the literal interpretation in both English and Persian is carrying or taking something which is already abundant in the target place, such as coal to Newcastle or cumin to Kerman, respectively. In this view the translator translates thought for thought and reflects what the original author most likely meant. A good translation must reliably replicate the meaning of the text without sacrificing its readability (Orusler, 2008).

Equivalence is a progress of achieving the closest natural equivalence by choosing the most appropriate translation method (Chen, 2010) and Nida's theory has become a standard or ideal that many modern translators have attempted to attain. This article investigates English sewing frame idiomatic expressions in relation to their Persian idiomatic equivalences based on Nida's Dynamic Equivalence Theory.

\section{The Frame of Sewing}

A sewing frame is inclusive of specific tools and materials. There are many idioms which are constructed around this frame in different languages. Understanding this frame in relation to the structure of idioms requires a cognitive semantic process.

In the process of sewing, two pieces of cloth or leather are joined by means of thread that is driven through by a needle. The needle which is an essential tool for sewing is a small thin object made of steel. It has a sharp point at one end and a hole at the other end (Concise Oxford Dictionary, $10^{\text {th }}$ Eds). The hole is called the needle eye. 
Needles and thread perform their functions in close relation to the other. In other words, neither of them can perform without the presence of the other. Thread is a long, thin strand of cotton, nylon or other fibers that is driven by a needle to form stitches.

Stitches are loops of thread or yarn resulting from a single pass or movement of a needle in sewing, knitting, or crocheting (COD, $10^{\text {th }}$ Eds.). Based on aforementioned discussion, both the needle and thread are essential for sewing. In order to accomplish that, the thread must be passed through the needle eye. In other words, the needle needs to be threaded.

When performing the task of sewing, the pattern of cloth must be prepared, firstly. A pattern is a shape used as a guide for making something. For sewing it is a thin piece of paper used when cutting materials to make clothes (LHLD, P.356). Pins are used to fix the pattern on cloth before cutting out the desired shape. A pin is a thin piece of metal with a sharp point at one end and a round head at other end, used for fastening pieces of cloths while making clothes.

Sewing is an activity that one may employ to mend a hole or an opening in the cloth or garment, or in the production of items of clothing such as coats, jackets, skirts, etc. In order to produce an item from cloth, once the pattern has been selected, the tailor cuts out the desired shape with scissors fastens the pieces together by means of pins, and then sews. Some clothes like coats and jackets need a lining. The final product of the process will be a garment.

Keeping the discussion going, the frame of sewing creates idioms in English and other languages. These idioms reference sewing tools and materials in their constructions to connote and express ideas. All in all, the main purpose of this article is to explain English idiomatic expressions and their idiomatic equivalences in Persian in order to understand to what extent they overlap.

\section{Method}

\subsection{Data Source and Collection}

This study used a number of English websites on idioms to collect the data, including: http://www.UsingEnglish.com/idiom.asp , http://www.fle135-idim.pbwork.com , http://goenglish.com/idiom.asp and http://www.idiomeanings.com . Research works on sewing frame metaphors, especially Metaphorical Extensions of the Sewing Frame in the Foreign Language Classroom (Uberman, 2008), contain helpful data. In addition, two Persian dictionaries were used, Farhang-e-Estelaahaat-e-Aamiyaneh and Zarb-al-Masalhaay-e-Farsi, to find Persian idiomatic expression counterparts.

\subsection{Procedure}

First the researchers compiled the idiomatic instances in English and Persian from the sources mentioned above. Then English samples were classified according to the sewing item they contain (e.g. pin, needle, thread, etc.). In addition, each Persian idiomatic expression with its English phonetic representation (EPR, hereafter) and its English equivalence translation (EET, hereafter) were listed along side its English counterpart. After that, idioms were explained connotatively and presented in either language. Researchers used Google's search engine to identify the Persian idiomatic instances in the text. Finally, English and Persian samples were compared to each other qualitatively.

\subsection{Data Analysis}

Having chosen an equivalence approach and considering Nida's Dynamic Equivalence theory, data from the study were qualitatively analyzed. English idiomatic expressions and their Persian equivalences were classified based on the elements that were used in the structure of idioms (e.g. pin, needle, thread, etc.) and then their figurative meanings were compared and described.

\subsubsection{Idiomatic expression in frame of sewing}

Idiomatic sewing frame expressions are large in number. Many idiomatic expressions may be found in the source and target languages that have similar meanings and that can be applied in the same contexts, although they may appear in different form and vocabulary. On the other hand, there are many idiomatic expressions that do not have any equivalence in the target language. This article makes mention of some of these selected instances.

4.3.1.1. Idioms that contain needle and pin in English:

4.3.1.1.1. Look for a needle in the haystack.

در انبار كاه دنبال سوزن كثنن

ænb^rə k^h du:nb^lə su:zæn gæshtæn/

EPR: $\quad /$ dær

EET: Look

for a needle in a hay store. 
If trying to find something is like looking for a needle in a haystack, it means that it is very difficult, if not impossible to find among everything around it (Internet: http://www.UsingEnglish.com/idiom.asp). Needle is a small, thin object. Considering connotation, such properties of a needle implies that finding something small among a lot of things everywhere is impossible. The Persian equivalent uses the same source to imply the meaning but in place of haystack it includes hay store.

English example: As in looking for that screw in Dean's workshop amounts to looking for a needle in a haystack (Internet http://www.yourdictionary.com/idioms ).

$$
\text { سبستم ر اهنمايي نمايشخاه ضعيف است و بيدا كردن كتاب در نمايشخاه مثل كثنن دنبال سوزن در انبار كاه است. }
$$

EPR: /si:stəmə r^hnæm^i:yə næm^yəshg^h zæ?i:f æst væ pəi:d^ kærdænə kət`b dær næm^yəshg^h məslə gæshæn du:nb^l su:zæn dær ænb^r k^h æst/.

EET: The guidance system of a book fair is not good and finding a book is as difficult as looking for a needle in a hay store.
4.3.1.1.2. To be on needles
اهل جماعت بخيه بودن

bæxi:yəh bu:dæn/

EPR: / æhlə jæm^tə

community

EET: To be from stitch

This idiom is a colloquial American English expression referring to drug abuse or to one who is addicted to narcotics. The Persian counterpart conveys both the same connotation and the same frame.
4.3.1.1.3 .Pin someone down
به جهار ميخ كثيدن

EPR: /bə ch^^^^r mi:x kəshi:dæn/

EET: Nail someone down by four pins.

The pin seems to be the element that holds a person in a position which makes it impossible for them to move or act the way they would wish to, in exactly the same way as the pieces of cloth that are pinned in order to restrict their freedom of movement. The Persian idiomatic counterpart uses nail in its structure to create such a cognitive semantic process.

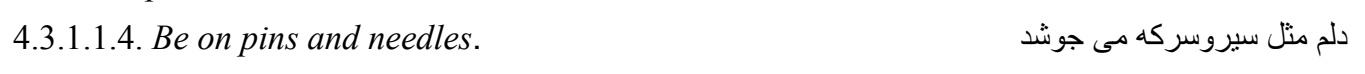

məslə si:r væ sərkəh mi:ju:shæd/

EPR: $\quad /$ dəlæm

boils like vinegar and garlic.

EET: My stomach

This idiom connotes a nervously anxious situation, as in He was on pins and needles waiting for the test results. It is used mainly in American English to represent an occasion of being anxious and unable to relax, particularly while waiting for something important (Uberman, 2008). In addition there is another idiom with the same connotation in English, namely 'I have a butterfly in my stomach' to express the feeling of anxiety.

English example: I am on pins and needles waiting for new Britney Spears album to come out. I cannot wait.

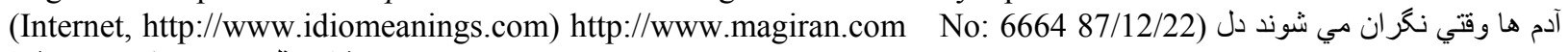
شان مثل سيرو سركه مي جوشد!

EPR: / `dæmh^ væqti: nəgær^n mi:shævænd dələsh^n məslə si:r væ sərkəh mi:ju:shæd/. (Internet,

EET: When people worry about something their stomach boils like vinegar and garlic.
4.3.1.1.5. Pin one's ear back.
آويزه ىُش كردن

EPR: / `vi:zəhyə gu:sh kærdæn/

\section{EET: To hang on ear}

This idiom implies listening carefully to something, often an order, e.g.: Pin back your ears, he could be about to say something important. In Persian earrings and ears are used to connote the same context, as earrings have pins for 
hanging on ears. Therefore when someone considers the words like earrings for ears he/she listens to something carefully.

اين نكته را تمامي بيمار ان ديابتي بايد آويزه ي كوش خود كنند كه افز ايش قند خون به بزشك و بيمار فرصت كافي مي دهد تا اقدامي براي بهبود حال

EPR: / i:n nuktə r^ tæm^mi:yə bi:m^^^n di:y^bəti: b^yæd ^vi:zəhyə gu:sh xu:d ku:nænd kə æfz^yəshə qændə xu:n bəh pəzəshk væ bi:m^r fu:rsæt k^fi: mi:dəhæd t^ əqd^mi: bær^y bəhbu:d h^l u: ænjæm dəhænd/.

EET: Diabetic patients have to hang this tip on their ears that an increase in blood sugar will provide a chance for both patient and physician to do something to cure him.

\subsection{Have pins and needles}

$$
\text { سوزن سوزن شدن }
$$

EPR:/ su:zæn su:zæn shu:dæn/

EET: To feel pins and needles.

To have pins and needles is to have a tingling sensation in a part of the body, for example an arm or a leg, when it has been in the same position for a long time (www.learn-english-today.com ).This is comparable to the feeling experienced when pins are pressed against the skin. The Persian idiomatic expression implies the feeling of paresthesia (http://www.forum.iransalamat.com) or inserting needles in some part of the body like legs. When one has not moved a part of their body for an extended period of time, the supply of blood has stopped flowing properly to that area thus causing upon movement a feeling similar to walking on needles.

4.3.1.2. Idioms that contain thread in English:

\subsection{Hang by a thread.}

$$
\text { بها مويى بند بودن }
$$

EPR: / bəh mu:i: bænd bu:dæn/

\section{EET: Hang by a hair}

If something hangs by a thread, there is a very small chance indeed of it being successful or surviving (Internet http://www.UsingEnglish.com/idiom.asp). This idiom is used with reference to people's lives and also means that the life of a person in question is not expected to last much longer and so they are very likely to die, or face some form of mortal peril. In Persian people use hair instead of thread, because a string of hair is so thin and it is expected to tear so whatever hangs by a string of hair, especially a person's life, is not expected to last much longer.

4.3.1.2.2. He who holds the thread holds the ball.

ku:j^ bəx^b^næd/

lead the camel.

Both of the described phrases connote that a person has control over the situation, knows all its details and is in charge. In the Persian counterpart camel chain and cameleer are used instead of thread and the ball.

4.3.1.2.3. Lose the thread كلام قطع كردن

EPR: /rəshtəh kælæm qæt? kærdæn/

EET: To cut the speech thread

If you lose the thread of something such as a conversation or a story, you are unable to follow it.
EPR: /ægær æli: s^rəb^n æst mi:d`nad shu:tu:r r^

EET: If Ali is the cameleer, he knows where to 
English example: "There were so many interruptions during the film that I completely lost the thread."(www.learn-english-today.com).

$$
\text { زن رشته كلام همسرش را قطع كرد و كفت: ناهار اماده است. }
$$

www.tebyan-ardebil.ir/description.aspx?id=1315 )

EPR: /zæn rəshtəhyə kæl^mə hæsæræsh r^ qæt? mi:ku:næd væ mi:gu:yæd n^h^r h`zər æst/

EET: The wife cut hers husband's speech thread and said, "Lunch is ready".

The Persian idiomatic expression uses the same source to imply the meaning, but uses the verb "cut" instead of "lose".

4.3.1.3. Idioms that contain stitch in English:

\subsection{A stitch in time saves nine.}

dæhi: bæqi:yə /

$$
\text { جو به موقع زنى يك بخيه ز زبارگى نجات دهى بقيه }
$$

EPR: / chu: bə mu:qə? zæni: tu: yək bæxi:yə zə p^rəgi: nəj^t

EET: A stitch in time, save the rest from rip apart

A stitch in time saves nine connotes that if you make small repairs now, it is much better than making large repairs later because it will only get worse, like a hole in clothes that requires stitching. (Internet, http://www.UsingEnglish.com/idiom.asp ). In this case the connotation and the source domain of its Persian equivalent is the same.

English example:

A: Are you going to start exercising? You've gained a bit of weight.

B: I only gained five pounds! I'll exercise if I get fatter.

A: But you should start soon, after all, a stitch in time saves nine. It's easier to lose five pounds than it is to lose twenty-five!

B: You're right! (Internet, http://www.idiomeanings.com)

4.3.1.3.2. In stitches. از خنده روده بر شدن

EPR: /æz xændə ru:dəh bu:r shu:dæn/

To rip apart one's intestine due to laughter

EET:

This idiomatic expression describes someone who is laughing uncontrollably. In an attempt to trace the possible origin of such a phrase, one might try to envisage a person laughing so much that they start to 'fall apart' and stitches need to be used to keep them in one piece(Uberman,2008). Its Persian equivalent refers to a person who laughs so uncontrollably that it seems his intestine will rip apart due to the intensity of his laughter.

English example: Ask Peter to tell you his joke about the woman with the poodle. He will have you in stitches.

Persian example:

از تماثشاى كارنون برهى ناقلا همه از خنده روده بر شديم

EPR:/ æz tæm^sh^y ə k^rtu:n e bærəy ə n^qu:1^ æz xændə ru:də bu:r shu:di:m/

EET: Watching the Shuan the Sheep cartoon makes us rip apart our intestines with laughter.

4. 3.1.4. Idioms that contain cloth and clothe.

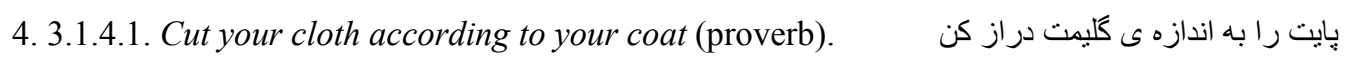

bə ænd`zəy ə gəli:mæt dər^z ku:n/

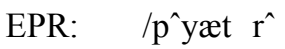

EET: Lay your feet

according to your rug.

You must adapt according to the resources available to you. This idiomatic expression comes from the idea of a tailor adapting what coat he could make according to how much fabric he had. The Persian equivalent connotes the same concept but with different lexical forms. Both English and Persian proverbs seem to imply the necessity to limit the extent of one's ambitions in accordance to his possessions. The Persian counterpart connotes the same concept, but with different vocabulary and constructs. كليم/gali:m/is a kind of short coarse carpet which was used in 
the Persian culture to sit on. According to this proverb each person has to lay his feet on his rug (كلي/gəli:m/) without taking of anyone else's possessions.

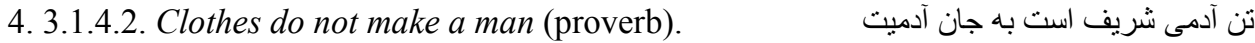 \\ نه همين لباس زيباست نثان آدميت}

$j^{\wedge} n$
EPR: /tæn ə ^dæmi: shæri:f æst bə

d’mi:yæt

næ hæmi:n ləb^s ə zi:b^st nəsh^n ə ^dæmi:yæt/

EET: Beauty is skin deep; beautiful clothes are not the symbol of civility.

It implies that clothes cannot reflect a person's character or their qualities. They simply modify or improve a person's outside appearance .The Persian equivalent is a verse of Saa'di, a famous Persian poet, that offers the same concept. It says that people's humanity makes a man not their outside appearance.

4. 3.1.5. Idioms that contain knot.

4. 3.1.5.1.Knotty problem.

كره در كار

افنتادن

EPR: /gərəh dær kr u:ftdæn/

EET: To fall knots in the work.

Knots are an unwelcome occurrence in sewing that are often unavoidable. This idiom is activated around the experience that it takes a long time to get rid of knots. When knots appear they slow done the whole process of sewing. Hence, it seems this idiomatic expression indicates a problem that is complicated and hard to solve both in English and in Persian.

\subsection{Idiomatic Expressions in the Frame of Sewing without Persian Idiomatic Equivalences}

There are idiomatic expressions in every language that do not have a TL language equivalent. Whenthe SL unit does not have a TL equivalent it is called zero equivalence (Kade, 1968).

4.4.1. One can hear a pin drop.

To say that one can hear a pin drop means that it is so quiet that the slightest noise can be heard. A pin is a small, thin, light object which produces a noise which is inaudible to the human ear when dropped to the ground. Imagining a pin dropping highlights the notion of silence in this lexical phrase.

Example: "Wilma and I were so happy when we moved out of the city into the countryside. Our new house is so quiet; we can hear a pin drop".

4.4.2. To lose a knot from one's tongue. (To start speaking).

Seeing his wrong behaviors, the woman lost a knot from her tongue.

4.4.3. Tie the knot (get married).

4.4.4. Do not stitch your seam before you have tackled it. (Penguin Dictionary of Proverbs, p.118).

This idiomatic expression is a piece of advice against haste and recklessness. It is always better to check whether something is properly planned, arranged or whether it works accurately before finalizing a task or before it assumes its final shape (Uberman, 2008).

4.4.5. The thread of Aridance.

According to Greek mythology, the goddess Aridance presented Theseus with a ball of thread to help him find his way back and get out of the labyrinth. It can hence be understood to symbolize escape (Uberman, 2008).

4.4.6. It is difficult to pick up the threads when you have been traveling for so long.

This implies that to begin something again after a long period, especially a relationship or way of life is difficult (LDCE, P.1505).

4.4.7. To thread one's way through something.

To understand this idiom we tend to imagine a tight passage, as in the eye of the needle, a place with hardly any space for someone to move through effortlessly. 


\subsubsection{Sewing bee (LDCE, 2003:120).}

It is an informal idiomatic expression functioning in American English to describe an occasion when people, usually women, meet in order to do a particular type of work.

\subsubsection{To sew something up.}

This idiom refers to completing a deal, contract, etc. The process is compared to sewing up pieces to make a suitable piece of clothing.

Example: He was hoping to get the deal sewn up on Friday and fly back from Hong Kong on Saturday (Cambridge International Dictionary).

\subsubsection{Not have a stitch on.}

It means "to be wearing no clothes". Someone who does not have a stitch on is wearing no clothes and is therefore completely naked .The notion was adopted in a story for children written by $\mathrm{H}$. Ch. Anderson entitled The Emperor's New Clothes. The Emperor was so vain that he wanted to look his best and constantly requested fashionable, new clothing. Once a couple of lazy men promised the Emperor they would sew clothes for him out of special clothes, which could not be seen by foolish people. They managed to persuade the Emperor to believe them and so they deceived the vain monarch. As he was walking down the street in clothes made of cloth that was not really there, he did not have stitch on (Uberman, 2008).

Example: "When the doorbell rang, he didn't have a stitch on!"

4.4.11. Pin something on a person.

If you pin a crime or the blame for something on someone, you accuse them of having done it, often when this is not true. (Cambridge International Dictionary Online)

\section{Example: When the theft was discovered, he tried to pin the blame on one of his colleagues.}

\subsubsection{Get the needle.}

When someone gets the needle (informal British English) they become angry.

\subsubsection{Sharp as a needle.}

When someone is described as being as sharp as a needle they are meant to be intelligent, quick witted and perceptive (Uberman, 2008).

\section{Conclusion}

The findings indicate that culture plays an important role in the construction of idioms. Furthermore, since culture-bound expressions are unique to any language, translators must develop an adequate cultural awareness of both source and target language (e.g. English and Persian in our study). From English and Persian idiomatic expressions that stem from their respective cultures, researchers take note that different languages take various elements as the source to imply the similar connotations. The study shows that except for a few instances, Persian idiomatic counterparts use other sources than the frame of sewing to connote the same ideas. In addition, any overlap is more connotatively oriented. There are some idiomatic expressions in the sewing frame in English that do not have any equivalence in Persian.

\section{Acknowledgment}

I would like to give my sincere thanks to my supervisor ,professor Abbass Eslami Rsekh at University of Isfahan, Iran for his considerable support ;professor M.Barati in Canada for his cheerful encouragements; and Lorri Wallace in California for her setting the eyes on this article.

\section{References}

Catford, J. (1965). A Linguistic Theory of Translation. London: Oxford University Press.

Chen, L. (2009). On literal translation of English idioms. English Language Teaching 2(2), 164-166

Chen, L. (2010).On integrated translation approach of English idioms. Journal Language Teaching and Research 1(3), 227-230.

Fergusson, R. (1993).Penguin Dictionary of Proverbs. London: Penguin Book Ltd.

Ji-Xin, Q. (2009) .On trainability of idioms.Sino-Us English teaching 6 (2), 57-60

Najafi, A. (1997). Farhang - e-Estelahat-e- Aamiyaneh. Tehran: Entesharat-e-Nilufar 
Mirzaei, M. \& Baluch, H. (1997). Zarb-al-Masalhay-e-Englisi be Farsi. Tehran: Sazman-e-Entesharat

Ni, L. (2009). For "translation and theories". English Language Teaching 2 (2), 78-83

Nida, E. (1964). Toward a Science of Translation. Leiden: E. J.Bil

Nida, E. (1993).Language, Culture and Translation. Shanghai: Shanghai Foreign Language Education Press.

Oursler, H. (2008). Which Bible Translation is best.

Soanes, C. \& Hawker, S. (2008).Compact Oxford Dictionary of current English (3rd Eds.).New York: Oxford University Press.

Speake, J. (Ed.) (2008).The Oxford dictionary of proverbs. (5th Eds.).Oxford: Oxford University Press.

Summers, D. (2003).Longman Dictionary of Contemporary English, The Living Dictionary. Harlow: Pearson Education Limited.

[Online] Available: http:// www.file135-idiom.pbwork.com

[Online] Available: http:// www.UsingEnglish.com

[Online] Available: http:// www.goenglish.com/idiom.asp

[Online] Available: http:// www.idiomeanings.com/idiom

[Online] Available: http:// www.yourdictionary.com

[Online] Available: http:// www.cambridge.dictionary.org

[Online] Available: http:// www.tebyan-ardebil.ir 